voor exploitatie van zijn portret door Albert Heijn was gevraagd. ECV en EMM hebben zich aan de zijde van Albert Heijn gevoegd in de procedure.

De rechtbank stelt vast dat niet ter discussie staat dat eiser toestemming heeft gegeven aan de Stichting voor het gebruik van de aan hem individueel toekomende portretrechten ten behoeve van de exploitatie van collectieve commerciële rechten. De rechtbank onderzoekt vervolgens of deze toestemming zich mede uitstrekt tot de promoties van het portret van eiser ten behoeve van de voetbalplaatjesactie van Albert Heijn. Hierbij neemt de rechtbank onder meer in ogenschouw dat art. 22 cao geen limitatieve opsomming betreft van het exploiteren van collectieve commerciële rechten en dat de gedachte achter de bepaling kennelijk is dat het om gezamenlijke in het economisch verkeer verzilverbare aanspraken van de voetbalclubs en -spelers gaat, waarbij het collectief centraal staat en niet het individu. Volgens de rechtbank staat het collectief centraal nu juist de voetbalplaatjesactie gaat om het bij elkaar sparen van alle collectieve plaatjes (alle spelers en andere plaatjes, zoals speelsters van het Nederlands damesteam, clublogo's, trainers, en teamfoto's).

De rechtbank is voorts van oordeel dat Albert Heijn haar voetbalplaatjesactie moet kunnen promoten op de wijze zoals zij dat heeft gedaan. Weliswaar zijn er posters en berichten op social media-kanalen geopenbaard met uitsluitend het portret van eiser dan wel met uitsluitend portretten van een aantal van de andere voetbalspelers, doch deze posters en berichten maken gezien hun context onmiskenbaar onderdeel uit van een groter geheel, namelijk de promotie van de voetbalplaatjesactie als geheel. Evenredig en gelijkmatig gebruik van de (individuele) portretten van alle voetbalspelers is voor de promotie van de voetbalplaatjesactie geen vereiste volgens de rechtbank. Het gaat daarnaast bij de promotie van de voetbalplaatjesactie om gebruik van het portret van eiser dat redelijkerwijs was te voorzien omdat dit een gebruikelijke wijze van promotie is bij een dergelijke spaaractie. De rechtbank komt tot de conclusie dat de toestemming van eiser ten behoeve van de exploitatie van de collectieve commerciële rechten, waaronder via de voetbalplaatjesactie, mede wordt geacht te omvatten toestemming voor de promotie van de voetbalplaatjesactie zoals Albert Heijn dat heeft gedaan. De vorderingen van eiser worden afgewezen.

NB. Het is niet ongebruikelijk in Nederland dat profsporters, clubs of bonden toestemming geven voor het (collectief) exploiteren van hun portret tezamen met dat van andere sporters. In het profvoetbal is deze toestemming in de geldende cao verankerd. De reikwijdte van collectieve exploitatie kan daarbij ter discussie komen, zoals in de onderhavige zaak, waarin werd geoordeeld dat de toestemming voor collectieve exploitatie van profvoetballers mede wordt geacht te omvatten redelijkerwijs voorzienbare promotieactiviteiten met gebruik van individuele portretten.
VSZ 2021/5

College van Arbiters KNVB 30 oktober 2020, nr. 1529 (Maletic/PSV)

Hoewel jeugdtrainer Maletic onterecht door PSV op staande voet is ontslagen, gaf zijn handelen aanleiding tot een matiging van de ontslagvergoedingen.

Met ingang van 1 juli 2019 trad Stefan Maletic (Maletic) voor bepaalde tijd voor de duur van twee jaar in dienst bij PSV N.V. (PSV) in de functie van jeugdtrainer tegen een bruto jaarsalaris van EUR 30.500 ex emolumenten. In de arbeidsovereenkomst ontbrak een tussentijds opzegbeding.

Op initiatief van Maletic heeft er in april 2020 tussen hem en een contractspeler van PSV WhatsApp-contact plaatsgehad over een mogelijke transfer van de speler naar een voetbalclub in de Emiraten. Op 1 mei 2020 heeft hierover een gesprek plaatsgevonden tussen PSV en Maletic, waarin PSV Maletic te kennen gaf het niet te accepteren dat hij heeft getracht een speler van PSV te bewegen tot een transfer. Ondanks een gedeeltelijke ontkenning en verontschuldigingen van Maletic, liet PSV hem weten geen vertrouwen meer te hebben in een vruchtbare voortzetting van de arbeidsovereenkomst. PSV zond Maletic op 1 mei 2020 in concept een vaststellingsovereenkomst ter beëindiging van de arbeidsovereenkomst met het verzoek deze overeenkomst nog dezelfde dag voor 23.00 uur te tekenen, met daarbij de opmerking dat wanneer hij niet akkoord ging, PSV nadere juridische stappen zou nemen. Maletic heeft de overeenkomst niet getekend, waarna PSV hem per brief, die door Maletic op 3 mei 2020 is ontvangen, op staande voet heeft ontslagen wegens het voor - kort gezegd eigen zakelijk gewin trachten een werknemer van PSV te bewegen zijn arbeidsovereenkomst met PSV te beëindigen. In de brief is voorts opgemerkt dat PSV hem in het gesprek op 1 mei 2020 te kennen heeft gegeven dat zijn arbeidsovereenkomst werd opgezegd wegens een dringende reden ex art. 7:677 BW. Maletic heeft de opzegging per 1 mei 2020 betwist, zich verzet tegen het ontslag en zich beschikbaar gesteld om zijn werk te hervatten. In de procedure heeft Maletic zich neergelegd bij de beëindiging per 1 , respectievelijk 3 mei 2020 en ontslagvergoedingen gevorderd.

Volgens de arbitragecommissie is niet komen vast te staan dat Maletic op 1 mei 2020 door PSV op staande voet is ontslagen. Voorts is de arbitragecommissie tot het oordeel gekomen dat de brief van 3 mei 2020 rechtsgevolg mist, omdat daarin is verwezen naar de opzegging op 1 mei 2020 die naar het oordeel van de commissie niet is komen vast te staan. Overigens heeft de arbitragecommissie geoordeeld dat een ontslag op staande voet niet met terugwerkende kracht kan worden gegeven, in die zin dat PSV met de brief van 3 mei 2020 de arbeidsovereenkomst dus niet per 1 mei 2020 met onmiddellijke ingang heeft kunnen doen beëindigen. Op 
grond hiervan heeft de commissie geoordeeld dat de arbeidsovereenkomst niet met onmiddellijke ingang per 1, respectievelijk 3 mei 2020 rechtsgeldig is beëindigd.

In het kader van de gevorderde vergoedingen heeft de arbitragecommissie overwogen dat het handelen van Maletic ontoelaatbaar was, maar in het licht van de gegeven omstandigheden niet zodanig dat dit een ontslag op staande voet zou hebben gerechtvaardigd. De commissie heeft de vergoeding wegens het voortijdig verbreken van de arbeidsovereenkomst ex art. 7:677 lid $4 \mathrm{BW}$ derhalve toegewezen, maar wel gematigd tot een bedrag van EUR 16.000. De commissie heeft de billijke vergoeding, boven op de vergoeding wegens onregelmatige opzegging, afgewezen omdat Maletic zich niet heeft gedragen zoals van een goed werknemer verwacht had mogen worden en hij redelijk snel een nieuwe betaalde baan heeft gevonden na het ontslag bij PSV.

\section{VSZ 2021/6}

\section{Rb. Midden-Nederland 23 november 2020, \\ ECLI:NL:RBMNE:2020:5111 (VoetbalTV/AP)}

\section{VoetbalTV hoeft boete Autoriteit Persoons- gegevens van EUR 575.000 niet te betalen.}

VoetbalTV B.V. (VoetbalTV) was een in 2018 opgericht videoplatform voor het amateurvoetbal dat in opdracht van voetbalverenigingen video-opnamen makkte van amateurvoetbalwedstrijden van senioren en jeugdspelers ouder dan 13 jaar. VoetbalTV had meer dan 500.000 gebruikers. Op het platform van VoetbalTV konden gebruikers voetbalmomenten terugkijken, wedstrijden analyseren, gegevens verzamelen en delen met anderen. VoetbalTV bood ook een analysetool waar trainers/ analisten gebruik van kunnen maken. De Autoriteit Persoonsgegevens (AP) heeft bij besluit van 16 juli 2020 aan VoetbalTV een boete opgelegd ter hoogte van EUR 575.000 voor het onrechtmatig verwerken van persoonsgegevens omdat VoetbalTV zonder rechtmatige grondslag video-opnamen zou hebben gemaakt van een groot aantal amateurvoetbalwedstrijden en deze beelden verder zou hebben verspreid onder een groot publiek via haar platform. Dit zou in strijd zijn met de Algemene Verordening Gegevensbescherming (AVG). Door de handelwijze van VoetbalTV zijn volgens de AP de betrokkenen, waaronder veel minderjarigen, de controle over hun persoonsgegevens (voor een deel) kwijtgeraakt. VoetbalTV heeft beroep ingesteld tegen het besluit van AP bij de rechtbank. Hoewel VoetbalTV op 11 september 2020 failliet is verklaard, wordt het beroep door de rechtbank behandeld, omdat partijen reeds voor het faillissement voor een zitting waren uitgenodigd.

VoetbalTV voert bij de rechtbank aan dat zij persoonsgegevens mocht verwerken op grond van de journalistieke exceptie, alsmede omdat zij voor verwerking een gerechtvaardigd belang had en daarmee een wettelijke grondslag. De AP betwist deze stellingen en stelt dat het te gelde maken van persoonsgegevens nooit een gerechtvaardigd belang kan opleveren. De rechtbank oordeelt dat van de journalistieke exceptie geen sprake is, omdat het opnemen van de voetbalwedstrijden en het uitzenden daarvan aan het publiek in dit geval niet uitsluitend een journalistiek doel dient. De rechtbank volgt de AP echter niet in haar standpunt dat VoetbalTV geen gerechtvaardigd belang kan hebben omdat VoetbalTV een commercieel belang heeft. Het op voorhand uitsluiten van een bepaald belang als gerechtvaardigd belang, is in strijd met de Europese rechtspraak. De AP had het gerechtvaardigd belang op een meer open en flexibele manier dienen uit te leggen dan vast te houden aan een strikte toepassing. De AP heeft daarmee miskend dat het begrip 'gerechtvaardigd' belang vooral als buitengrens dient voor de beoordeling en niet als een drempel. De AP moet juist een onderzoek doen naar de belangen van VoetbalTV en vervolgens een afweging maken of zij door het uitzenden van de amateurvoetbalwedstrijden de privacy van betrokkenen ontoelaatbaar schendt. De manier waarop verweerder deze toetsing moet uitvoeren volgt uit de rechtspraak van het Hof van Justitie. Het beroep van VoetbalTV is dan ook gegrond en de rechtbank vernietigt het besluit van de AP waarin de boete was opgelegd. De rechtbank voorziet met toepassing van art. 8:72a Awb zelf in de zaak, in die zin dat zij geen ander besluit neemt in de plaats van het vernietigde besluit. Als gevolg daarvan is de boete geheel van tafel.

NB. Het gerechtvaardigd belang is vaak een grondslag voor verwerking van persoonsgegevens in de sport. Als deze uitspraak navolging krijgt, zullen sportorganisaties dan ook minder snel beperkt worden in de mogelijkheden om persoonsgegevens te verwerken. De AP legde reeds eerder een boete op van EUR 525.000 op aan de KNLTB voor de verkoop van ledengegevens aan sponsoren en legde daaraan ook ten grondslag dat een commercieel belang nimmer een gerechtvaardigd belang zou kunnen opleveren. ${ }^{3}$
3. Vgl. M. Jansen, KNLTB-boete: wie kaatst kan de bal verwachten of toch een misslag?, Computerrecht 2020/180. 